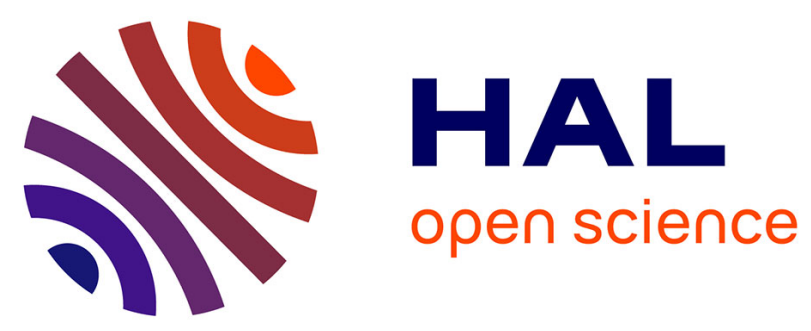

\title{
Mechanosynthesis of Noels-type NHC-Ruthenium Complexes and Applications in Ring-Opening Metathesis Polymerization
}

François Quintin, Julien Pinaud, Frédéric Lamaty, Xavier Bantreil

\section{- To cite this version:}

François Quintin, Julien Pinaud, Frédéric Lamaty, Xavier Bantreil. Mechanosynthesis of Noelstype NHC-Ruthenium Complexes and Applications in Ring-Opening Metathesis Polymerization. Organometallics, 2020, 39 (5), pp.636-639. 10.1021/acs.organomet.0c00013 . hal-02519408

\section{HAL Id: hal-02519408 \\ https://hal.umontpellier.fr/hal-02519408}

Submitted on 23 Nov 2020

HAL is a multi-disciplinary open access archive for the deposit and dissemination of scientific research documents, whether they are published or not. The documents may come from teaching and research institutions in France or abroad, or from public or private research centers.
L'archive ouverte pluridisciplinaire HAL, est destinée au dépôt et à la diffusion de documents scientifiques de niveau recherche, publiés ou non, émanant des établissements d'enseignement et de recherche français ou étrangers, des laboratoires publics ou privés. 


\title{
Mechanosynthesis of Noels-type NHC-Ruthenium Complexes and Applications in Ring-Opening Metathesis Polymerization
}

\author{
François Quintin, Julien Pinaud, Frédéric Lamaty,* and Xavier Bantreil*
}

ABSTRACT: The use of ball mills enabled the efficient mechanosynthesis of a variety of $N$-aryl, $N$-alkyl imidazolium salts and of corresponding NHC silver(I) complexes. Transmetalation with ruthenium via mechanochemistry allowed the rapid access (from 1.5 $\min$ to $1 \mathrm{~h}$ ) to complexes having a similar structure to Noels-type precatalysts. Evaluation of the complexes in the ring-opening metathesis polymerization of norbornene in different solvent, including nontoxic ones, showed a high catalytic activity for one of them, comparable to that of the Noels catalyst.

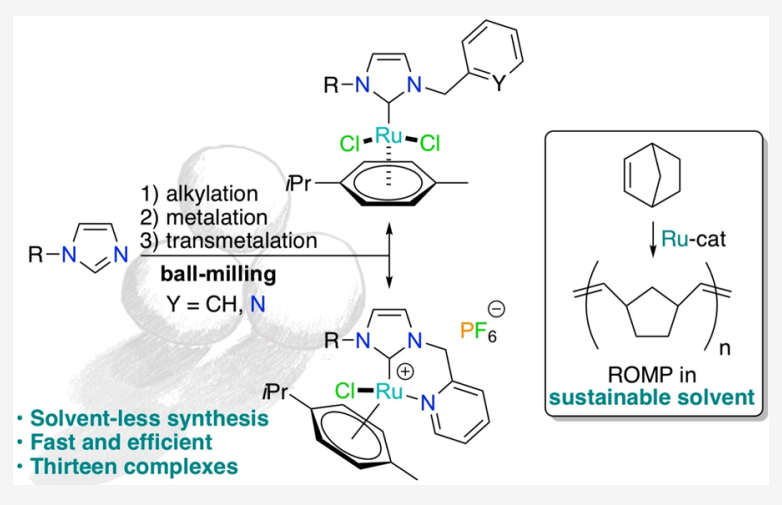

Cince its discovery, olefin metathesis has become an $\checkmark$ important chemical transformation in the academic as well as in the industrial world. ${ }^{1}$ In particular, ring-opening metathesis polymerization (ROMP) finds applications in the synthesis of useful polymer materials such as poly(norbornene) or poly(dicyclopentadiene). ${ }^{2}$ In regards to this reaction, the ruthenium-arene complex $\left[\mathrm{RuCl}_{2}\right.$ (p-cymene)(IMes)] (IMes = 1,3-bis(mesityl)imidazol-2-ylidene), also known as Noels' catalyst, was found to be highly active. ${ }^{3}$ Although benzylidene Grubbs-like complexes are still under intensive study in order to develop a universal catalyst, Noels' type complexes have less been investigated. Thus, we describe herein the mechanosynthesis of analogs of Noels-like complexes through alkylation of $\mathrm{N}$-arylimidazoles, silver metalation, and transmetalation in a ball mill, as well as their evaluation in ROMP of norbornene (NB). Mechanochemistry, including ball mills and reactive extrusion, was recognized in 2019 by IUPAC as an innovation that will change the world. ${ }^{4}$ This technology allows the avoidance of solvent in the reaction mixture, thus reducing the environmental impact of the reaction, and generally permits an increase of the reaction speed compared to solution-based methods. ${ }^{5}$ Additionally, it permits the synthesis of compounds inaccessible by other means. ${ }^{6}$ Of note, ball-milling was recently used for the synthesis of second- and third-generation Grubbsand Hoveyda-like complexes through a solvent-free carbene addition reaction. ${ }^{7}$ We thus desired to take advantage of our expertise in the preparation of metal complexes via ballmilling $^{8}$ for the synthesis of Noels-type olefin metathesis catalysts. $^{5 \mathrm{~b}}$

On the basis of our experience on the formation of $N, N$ dialkylimidazolium salts, ${ }^{8 \mathrm{e}}$ alkylation of $N$-mesityl- and $N-(2,6-$ diisopropylphenyl) imidazole was examined in a ball mill (Scheme 1). In a vibratory ball mill (vbm), milling $N$ arylimidazoles at $25 \mathrm{~Hz}$ with benzyl bromide in a PTFE jar with a $1 \mathrm{~cm}$ diameter stainless-steel ball allowed us to obtain full conversion into corresponding imidazolium salts 2 a and $2 \mathrm{~b}$, respectively, in less than $1.5 \mathrm{~h}$. No purification was required, and a simple extraction and filtration over Celite furnished the pure compounds in 97 and $93 \%$ yield. Similarly, compounds $\mathbf{2 c}$,d, which are bidentate ligand precursors, were obtained in $91 \%$ yield after milling of $\mathbf{1 a}, \mathbf{b}$ with bromomethylpyridine hydrobromide and sodium bicarbonate for $1.5 \mathrm{~h}$. Double nucleophilic substitution was also performed using 2,6di(bromomethyl)pyridine as alkylating agent. Milling frequency and time were increased to $30 \mathrm{~Hz}$ and $3.5 \mathrm{~h}$, respectively, to finally isolate $2 \mathbf{e}, \mathbf{f}$ in 94 and $91 \%$ yield.

Notably, the mechanochemical approach enabled the use of smoother conditions and shorter reaction times than those with solution conditions. ${ }^{9}$ As a representative example, synthesis of compound $2 \mathrm{e}$ requires 2 days when performed in refluxing dioxane ${ }^{9 \mathrm{a}}$ instead of $3.5 \mathrm{~h}$ under solvent-free milling conditions.

Imidazolium salts $\mathbf{2} \mathbf{a}-\mathbf{f}$ were then metalated using silver(I) oxide under solvent-free mechanochemical conditions. Of note, as milling jars are not transparent, there is no need to light protection usually necessary for the synthesis of light- 
Scheme 1. Alkylation of $\mathrm{N}$-Arylimidazoles and Silver Metalation

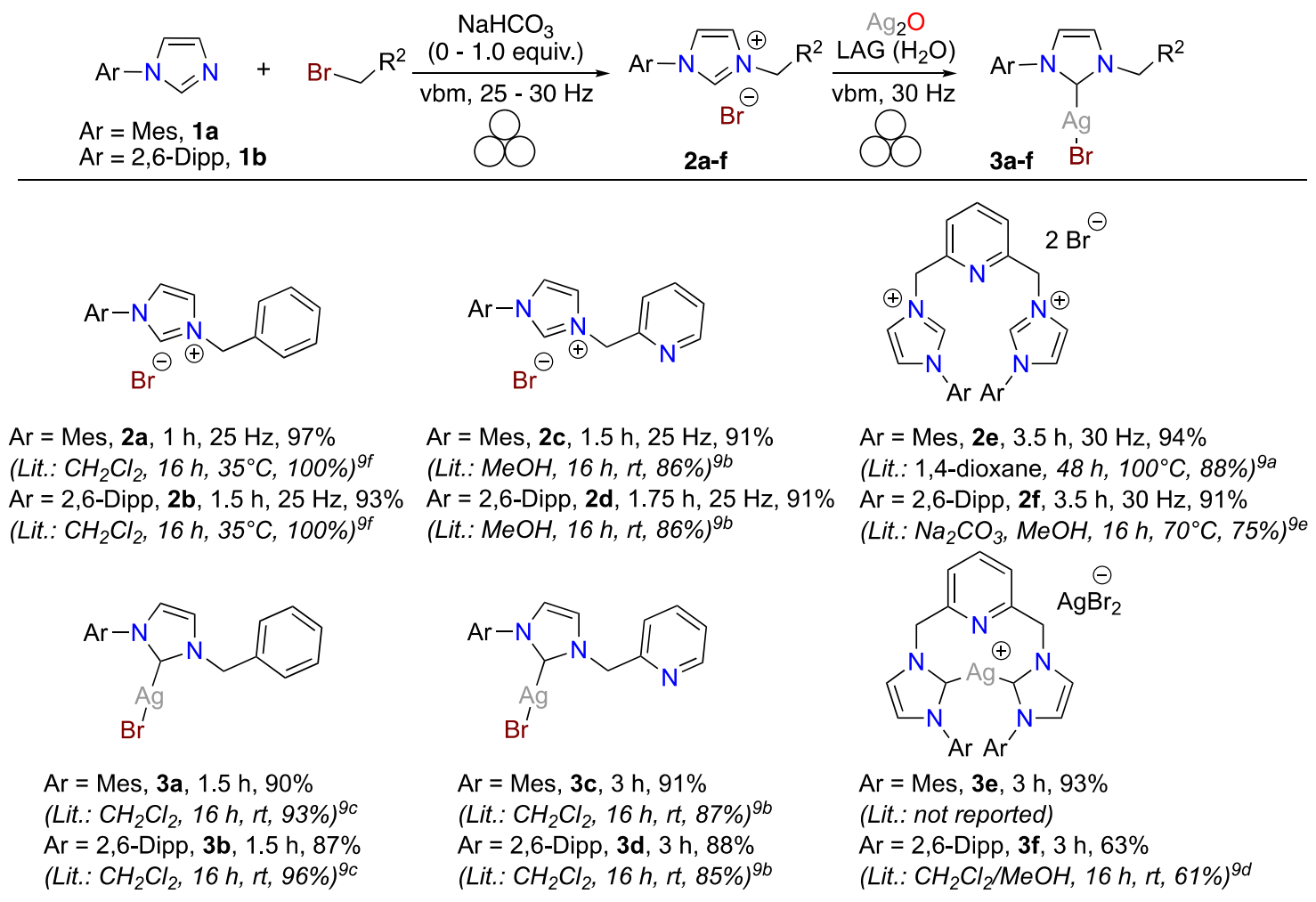

Scheme 2. Mechanosynthesis of Ruthenium Complexes

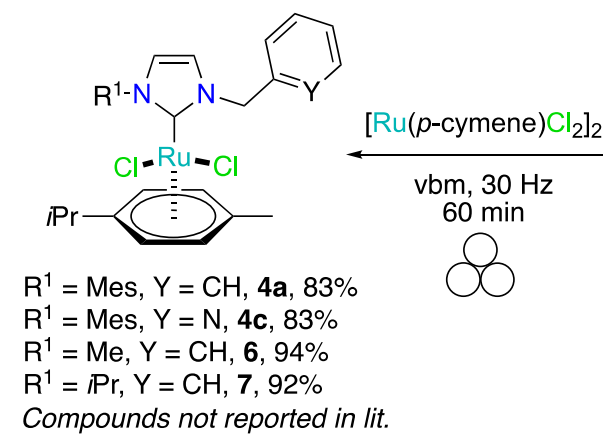

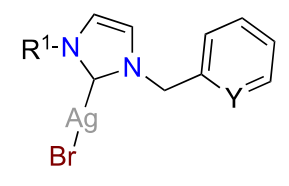

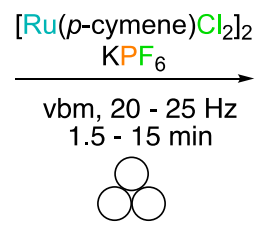

$\mathrm{R}^{1}=$ Mes, $5 \mathbf{a}, 25 \mathrm{~Hz}, 15 \mathrm{~min}, 97 \%$

$\mathrm{R}^{1}=\operatorname{Pr}, 9,20 \mathrm{~Hz}, 3 \mathrm{~min}, 62 \%$

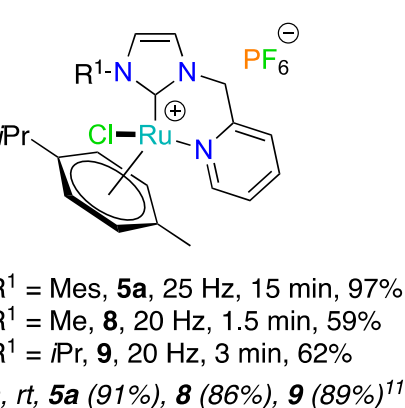

sensitive silver complexes. Contrary to what was observed in the metalation of $N, N$-dialkylimidazolium salts, ${ }^{8 \mathrm{e}}$ the reaction mixture was found to be not homogeneous in the milling jar. To solve this issue, addition of water as liquid grinding assistant $(0.3 \mu \mathrm{L} / \mathrm{mg}$ of reactants) revealed the paramount conditions. ${ }^{10}$ Under these conditions, metalation proceeded in $1.5-3 \mathrm{~h}$, and complexes $3 \mathrm{a}-\mathrm{f}$ could be isolated in yields up to 93\% (Scheme 1).

Silver complexes $3 a$ and $3 c$ were then milled with 0.5 equiv of $\left[\mathrm{Ru}(p \text {-cymene }) \mathrm{Cl}_{2}\right]_{2}$ at $30 \mathrm{~Hz}$ for $1 \mathrm{~h}$ in a stainless-steel jar (Scheme 2). Corresponding complexes $4 a$ and $4 c$ were both isolated in $83 \%$ yield. No coordination of the pyridine was observed in the case of $4 c$. To increase the scope of ruthenium complexes and compare them in ROMP, complexes 6 and 7, featuring methyl and isopropyl groups in place of the mesityl in the NHC ligand, respectively, were also mechanosynthesized. After $1 \mathrm{~h}$ of milling at $30 \mathrm{~Hz}$, complexes 6 and 7 were isolated in 94 and $92 \%$ yield, respectively. For the pyridine-containing compounds, addition of a stoichiometric quantity of $\mathrm{KPF}_{6}$ in the milling media enabled the chelation. However, such reaction was found sensitive to the milling conditions. Reaction of $3 \mathrm{c}$ with $\left[\mathrm{Ru}(p \text {-cymene }) \mathrm{Cl}_{2}\right]_{2}$ at $30 \mathrm{~Hz}$ for $1 \mathrm{~h}$ in the presence of $\mathrm{KPF}_{6}$ yielded a 90:10 mixture of $\mathbf{5 a} / \mathbf{2} \mathbf{c} \cdot \mathbf{P F}_{6}$, which could not be improved by a prolonged milling. To ensure full conversion and no side product formation, the milling frequency was reduced to $25 \mathrm{~Hz}$, and the material of the jar was changed from stainless steel to PTFE. A softer material such as PTFE will absorb more energy from the impacts of the ball than a harder one. 5a could be obtained as a pure compound after only $15 \mathrm{~min}$ of grinding at $25 \mathrm{~Hz}$. Similarly, complexes $\mathbf{8}$ and $\mathbf{9}$, featuring a methyl and isopropyl group instead of the mesitylene, respectively, could be formed in less than $3 \mathrm{~min}$ at $20 \mathrm{~Hz}$. As the transmetalation occurred efficiently, a simple recovery and filtration over Celite of the reaction mixture using 1,3-dioxolane as solvant, a green alternative to dichloromethane, furnished the pure compounds. As a comparison, in solution, $3 \mathrm{~h}$ of reaction in dichloromethane were required to obtain $\mathbf{5 a}, \mathbf{8}$, and $9 .^{11}$ Notably, the reaction of silver complexes $\mathbf{3 b}$ and $\mathbf{3 d}$, featuring a sterically hindered 2,6-diisopropylphenyl group, and $\mathbf{3 e , f}$, bearing 
tridentate ligands, with the ruthenium dimer resulted in the formation of the desired complex but with unidentified and inseparable side products.

The obtained ruthenium complexes were then evaluated in the ROMP of $\mathrm{NB}$, using a ratio precatalyst $/ \mathrm{NB}=1 / 500$ (Table 1). To compare the activity of the different precatalysts,

Table 1. Comparison of Mechanosynthesized Catalysts' Activity in the ROMP of Norbornene ${ }^{a}$

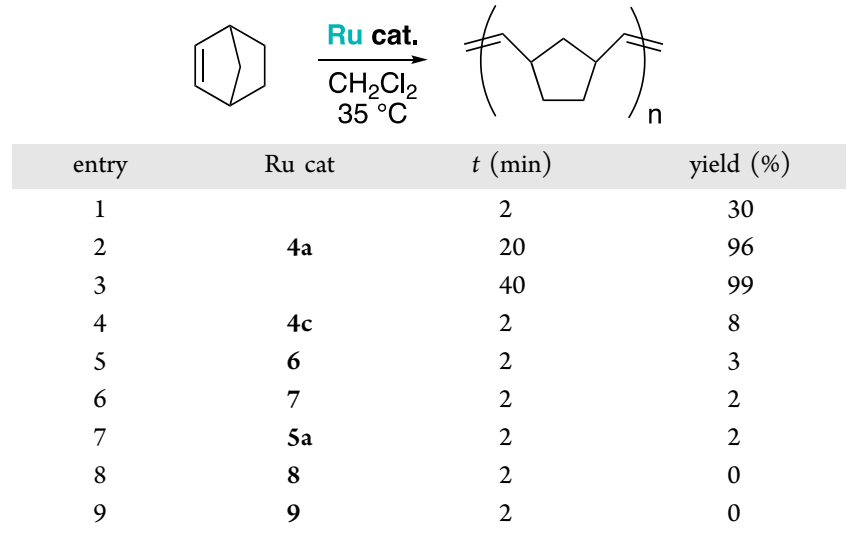

${ }^{a}$ Reaction conditions: norbornene $(5.32 \mathrm{mmol})$, catalyst $(0.01$ $\mathrm{mmol}), \mathrm{CH}_{2} \mathrm{Cl}_{2}(2.5 \mathrm{~mL}), \mathrm{N}_{2}$, and $35{ }^{\circ} \mathrm{C}$.

polymerization reactions were stopped after 2 min of reaction, by quenching with the addition of ethylvinyl ether, to determine the yield of isolated polymer. If complex $4 \mathbf{a}$ gave an interesting $30 \%$ yield in polynorbornene, then $4 c$, featuring a pyridine attached to the NHC, furnished only $8 \%$ yield, probably because of an unproductive coordination/decoordination of the pyridine during the catalytic cycle (Table 1, entries 1 and 4). Replacing the mesityl with a methyl or isopropyl group revealed detrimental as the isolated yield dropped to 3 and 2\%, respectively (Table 1, entries 5 and 6). Such behavior is in good agreement with the observations by Noels et al. regarding the ROMP of cyclooctene. ${ }^{12}$ Complexes 5a, $\mathbf{8}$, and $\mathbf{9}$, featuring a pyridine coordinated to the ruthenium center, were almost inactive in the ROMP of NB, due to a too strong chelation of the ruthenium (Table 1, entries 7-9). Attempts to activate these precatalysts by heating or adding $\mathrm{HCl}$ did not allow for any improvement. Thus, complex 4a was found to be the most active precatalyst for the ROMP of NB. When the reaction time was increased to 20 and $40 \mathrm{~min}$, gratifyingly, yields up to $99 \%$ were obtained (Table 1, entries 2 and 3). In order to find an ecofriendly solvent for ROMP, 4a was then evaluated in 1,3-dioxolane and DMC (dimethylcarbonate) in addition to dichloromethane (Figure 1). Even if the reaction was found to be faster in dichloromethane, the kinetic profiles were remarkable in 1,3-dioxolane and DMC since almost quantitative yields were obtained in $80 \mathrm{~min}$. In particular, ROMP proceeded more rapidly in 1,3-dioxolane than DMC. Of note, ROMP of NB with 4 a was compared to previously reported results using in situ generated Noels catalyst. ${ }^{13}$ Interestingly, the kinetics were found to be similar, proving that well-defined complex 4 a with an $\mathrm{N}$-benzyl, $\mathrm{N}$ mesityl NHC ligand possesses an excellent activity in ROMP. See the Supporting Information for details.

In conclusion, mechanochemistry enabled the efficient synthesis of $\mathrm{N}$-aryl, $\mathrm{N}$-alkyl imidazolium salts and of corresponding heteroleptic NHC-silver(I) complexes. In addition,

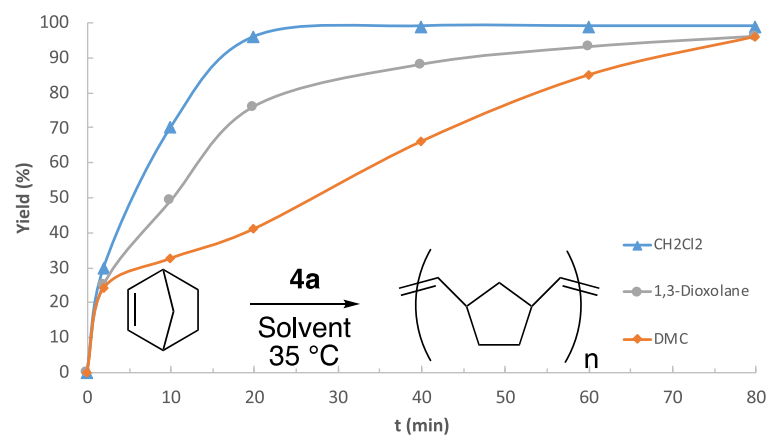

Figure 1. Effect of solvent in the ROMP of norbornene with 4a. Reaction conditions: norbornene $(5.32 \mathrm{mmol}), 4 a(0.01 \mathrm{mmol})$, solvent $(2.5 \mathrm{~mL}), \mathrm{N}_{2}$, and $35{ }^{\circ} \mathrm{C}$.

mechanotransmetalation allowed generating Noels' like ruthenium coordination complexes in short reaction times, from $1.5 \mathrm{~min}$ to $1 \mathrm{~h}$, and in excellent yields. These complexes were evaluated in the ROMP of NB in a series of solvents, and complex 4a exhibited interesting high kinetic activity, comparable to that of in situ generated Noels catalyst. Further study on the tuning of the NHC ligand in such complexes is ongoing in our laboratory.

\section{AUTHOR INFORMATION}

\section{Corresponding Authors}

Frédéric Lamaty - IBMM, Université Montpellier, CNRS, ENSCM, Montpellier CEDEX 5 34095, France; 이이.org/ 0000-0003-2213-9276; Email: frederic.lamaty@ umontpellier.fr

Xavier Bantreil - IBMM, Université Montpellier, CNRS, ENSCM, Montpellier CEDEX 5 34095, France; 이이.org/ 0000-0002-2676-6851; Email: xavier.bantreil@ umontpellier.fr

\section{Authors}

François Quintin - IBMM, Universite Montpellier, CNRS, ENSCM, Montpellier CEDEX 5 34095, France

Julien Pinaud - ICGM, Universite Montpellier, CNRS, ENSCM, Montpellier 34095, France; 으잉.org/00000003-4446-3771

\section{Notes}

The authors declare no competing financial interest.

\section{ACKNOWLEDGMENTS}

The Université de Montpellier, Centre Nationale de la Recherche Scientifique (CNRS) and Agence Nationale de la Recherche (grant no. ANR-16-CE07-0009-01) are acknowledged for funding. 


\section{REFERENCES}

(1) (a) Compain, P. Olefin metathesis of amine-containing systems. Beyond the current consensus. Adv. Synth. Catal. 2007, 349, 18291846. (b) Deiters, A.; Martin, S. F. Synthesis of oxygen- and nitrogencontaining heterocycles by ring-closing metathesis. Chem. Rev. 2004, 104, 2199-2238. (c) Grubbs, R. H.; Wenzel, A. G.; Chatterjee, A. K. In Olefin Cross-Metathesis; Elsevier Ltd., 2007; pp 179-205. (d) Hoveyda, A. H.; Zhugralin, A. R. The remarkable metal-catalysed olefin metathesis reaction. Nature 2007, 450, 243-251. (e) Grela, K., Ed. Olefin Metathesis: Theory and Practice; John Wiley \& Sons, Inc., 2014; pp 592. (f) Higman, C. S.; Lummiss, J. A. M.; Fogg, D. E. Olefin Metathesis at the Dawn of Implementation in Pharmaceutical and Specialty-Chemicals Manufacturing. Angew. Chem., Int. Ed. 2016, $55,3552-3565$

(2) Mol, J. C. Industrial applications of olefin metathesis. J. Mol. Catal. A: Chem. 2004, 213, 39-45.

(3) Delaude, L.; Demonceau, A. Retracing the evolution of monometallic ruthenium-arene catalysts for $\mathrm{C}-\mathrm{C}$ bond formation. Dalton Trans. 2012, 41, 9257-9268.

(4) Gomollon-Bel, F. Ten Chemical Innovations That Will Change Our World: IUPAC identifies emerging technologies in Chemistry with potential to make our planet more sustainable. Chem. Int. 2019, $41,12-17$.

(5) (a) Friščić, T.; Mottillo, C.; Titi, H. M. Mechanochemistry for Synthesis. Angew. Chem., Int. Ed. 2020, 59, 1018-1029. (b) Beillard, A.; Bantreil, X.; Métro, T.-X.; Martinez, J.; Lamaty, F. Alternative Technologies That Facilitate Access to Discrete Metal Complexes. Chem. Rev. 2019, 119, 7529-7609. (c) Tan, D.; Friščić, T. Mechanochemistry for Organic Chemists: An Update. Eur. J. Org. Chem. 2018, 2018, 18-33. (d) Howard, J.; Cao, Q.; Browne, D. L. Mechanochemistry as an emerging tool for molecular synthesis: what can it offer? Chem. Sci. 2018, 9, 3080-3094. (e) Andersen, J.; Mack, J. Mechanochemistry and organic synthesis: from mystical to practical. Green Chem. 2018, 20, 1435-1443. (f) Do, J.-L.; Friščić, T. Mechanochemistry: A Force of Synthesis. ACS Cent. Sci. 2017, 3, 13-19. (g) Rightmire, N. R.; Hanusa, T. P. Advances in organometallic synthesis with mechanochemical methods. Dalton Trans. 2016, 45, 2352-2362. (h) Wang, G.-W. Mechanochemical organic synthesis. Chem. Soc. Rev. 2013, 42, 7668-7700. (i) Takacs, L. The historical development of mechanochemistry. Chem. Soc. Rev. 2013, 42, 7649-7659. (j) James, S. L.; Adams, C. J.; Bolm, C.; Braga, D.; Collier, P.; Frišcić, T.; Grepioni, F.; Harris, K. D. M.; Hyett, G.; Jones, W.; Krebs, A.; Mack, J.; Maini, L.; Orpen, A. G.; Parkin, I. P.; Shearouse, W. C.; Steed, J. W.; Waddell, D. C. Mechanochemistry: opportunities for new and cleaner synthesis. Chem. Soc. Rev. 2012, 41, 413-447.

(6) Hernández, J. G.; Bolm, C. Altering Product Selectivity by Mechanochemistry. J. Org. Chem. 2017, 82, 4007-4019.

(7) Mukherjee, N.; Marczyk, A.; Szczepaniak, G.; Sytniczuk, A.; Kajetanowicz, A.; Grela, K. A Gentler Touch: Synthesis of Modern Ruthenium Olefin Metathesis Catalysts Sustained by Mechanical Force. Chem CatChem 2019, 11, 5362-5369.

(8) (a) Beillard, A.; Bantreil, X.; Métro, T.-X.; Martinez, J.; Lamaty, F. Mechanochemistry for facilitated access to $N, N$-diaryl NHC metal complexes. New J. Chem. 2017, 41, 1057-1063. (b) Beillard, A.; Bantreil, X.; Métro, T.-X.; Martinez, J.; Lamaty, F. Unraveling the synthesis of homoleptic $\left[\mathrm{Ag}(\mathrm{N}, \mathrm{N} \text {-diaryl-NHC })_{2}\right] \mathrm{Y}\left(\mathrm{Y}=\mathrm{BF}_{4}, \mathrm{PF}_{6}\right)$ complexes by ball-milling. Dalton Trans. 2016, 45, 17859-17866. (c) Pétry, N.; Vanderbeeken, T.; Malher, A.; Bringer, Y.; Retailleau, P.; Bantreil, X.; Lamaty, F. Mechanosynthesis of Sydnone-containing Coordination Complexes. Chem. Commun. 2019, 55, 9495-9498. (d) Beillard, A.; Métro, T.-X.; Bantreil, X.; Martinez, J.; Lamaty, F. $\mathrm{Cu}(0), \mathrm{O}_{2}$ and mechanical forces: a saving combination for efficient production of $\mathrm{Cu}-\mathrm{NHC}$ complexes. Chem. Sci. 2017, 8, 1086-1089. (e) Beillard, A.; Golliard, E.; Gillet, V.; Bantreil, X.; Métro, T.-X.; Martinez, J.; Lamaty, F. Expedient Mechanosynthesis of N,N-Dialkyl Imidazoliums and Silver(I)-Carbene Complexes in a Ball-Mill. Chem. Eur. J. 2015, 21, 17614-17617.
(9) (a) Serra, D.; Cao, P.; Cabrera, J.; Padilla, R.; Rominger, F.; Limbach, M. Development of Platinum(II) and -(IV) CNC Pincer Complexes and Their Application in a Hydrovinylation Reaction. Organometallics 2011, 30, 1885-1895. (b) Warsink, S.; van Aubel, C. M. S.; Weigand, J. J.; Liu, S.-T.; Elsevier, C. J. Bulky Picolyl Substituted NHC Ligands and Their Pd0 Complexes. Eur. J. Inorg. Chem. 2010, 2010, 5556-5562. (c) Flahaut, A.; Roland, S.; Mangeney, P. Allylic alkylation and amination using mixed (NHC)(phosphine) palladium complexes under biphasic conditions. J. Organomet. Chem. 2007, 692, 5754-5762. (d) Nielsen, D. J.; Cavell, K. J.; Skelton, B. W.; White, A. H. Methyl-palladium(II) complexes of pyridine-bridged bis(nucleophilic heterocyclic carbene) ligands: Substituent effects on structure, stability, and catalytic performance. Inorg. Chim. Acta 2006, 359, 1855-1869. (e) Danopoulos, A. A.; Tulloch, A. A. D.; Winston, S.; Eastham, G.; Hursthouse, M. B. Chelating and 'pincer' dicarbene complexes of palladium; synthesis and structural studies. Dalton Trans. 2003, 1009-1015. (f) Herrmann, W. A.; Köcher, C.; Gooßen, L. J.; Artus, G. R. J. Heterocyclic Carbenes: A High-Yielding Synthesis of Novel, Functionalized N-Heterocyclic Carbenes in Liquid Ammonia. Chem. - Eur. J. 1996, 2, 1627-1636.

(10) Bowmaker, G. A. Solvent-assisted mechanochemistry. Chem. Commun. 2013, 49, 334-348.

(11) Fernández, F. E.; Puerta, M. C.; Valerga, P. Ruthenium(II) Picolyl-NHC Complexes: Synthesis, Characterization, and Catalytic Activity in Amine $\mathrm{N}$-alkylation and Transfer Hydrogenation Reactions. Organometallics 2012, 31, 6868-6879.

(12) Delaude, L.; Demonceau, A.; Noels, A. F. Visible light induced ring-opening metathesis polymerisation of cyclooctene. Chem. Commun. 2001, 986-987.

(13) Pinaud, J.; Trinh, T. K. H.; Sauvanier, D.; Placet, E.; Songsee, S.; Lacroix-Desmazes, P.; Becht, J.-M.; Tarablsi, B.; Lalevée, J.; Pichavant, L.; Héroguez, V.; Chemtob, A. In Situ Generated Ruthenium-Arene Catalyst for Photoactivated Ring-Opening Metathesis Polymerization through Photolatent $\mathrm{N}$-Heterocyclic Carbene Ligand. Chem. - Eur. J. 2018, 24, 337-341. 